


\section{The Logic of Care}

What is good care? In this innovative and compelling book, Annemarie Mol argues that good care has little to do with 'patient choice' and, therefore, creating more opportunities for patient choice will not improve health care.

Although it is possible to treat people who seek professional help as customers or citizens, Mol argues that this undermines ways of thinking and acting crucial to health care. Illustrating the discussion with examples from diabetes clinics and diabetes self care, the book presents the 'logic of care' in a step by step contrast with the 'logic of choice'. She concludes that good care is not a matter of making well-argued individual choices but is something that grows out of collaborative and continuing attempts to attune knowledge and technologies to diseased bodies and complex lives.

Mol does not criticise the practices she encountered in her field work as messy or ad hoc, but makes explicit what it is that motivates them: an intriguing combination of adaptability and perseverance. The Logic of Care: Health and the problem of patient choice is crucial reading for all those interested in the theory and practice of care, including sociologists, anthropologists and health-care professionals. It will also speak to policymakers and become a valuable source of inspiration for patient activists.

Annemarie Mol is Socrates Professor of Political Philosophy at the University of Twente, the Netherlands. 



\section{The Logic of Care}

Health and the problem of patient choice

Annemarie Mol 
First published in 2006 with the title De logica van het zorgen. Actieve patiënten en de grenzen van het kiezen by Van Gennep, Amsterdam

Published 2008

by Routledge

2 Park Square, Milton Park, Abingdon, Oxon OX14 4RN

Simultaneously published in the USA and Canada

by Routledge

270 Madison Ave, New York, NY 10016

Routledge is an imprint of the Taylor \& Francis Group, an informa business

This edition published in the Taylor \& Francis e-Library, 2008.

"To purchase your own copy of this or any of Taylor \& Francis or Routledge's collection of thousands of eBooks please go to www.eBookstore.tandf.co.uk."

(C) 2008 Annemarie Mol

Translation and adaptation from the Dutch: Peek Language Services and the author.

Changes have also been introduced: there are differences throughout between the English and the Dutch version of this book.

All rights reserved. No part of this book may be reprinted or reproduced or utilised in any form or by any electronic, mechanical, or other means, now known or hereafter invented, including photocopying and recording, or in any information storage or retrieval system, without permission in writing from the publishers.

British Library Cataloguing in Publication Data

A catalogue record for this book is available from the British Library

Library of Congress Cataloging in Publication Data

Mol, Annemarie.

[Logica van het zorgen. English]

The logic of care: health and the problem of patient choice/Annemarie

Mol.

p.cm.

Includes bibliographical references.

1. Medical care-Evaluation. 2. Medical care-Quality control. 3. Patient satisfaction. 4. Patients-Civil rights. 5. Diabetes-Treatment-

Netherlands-Case studies. I. Title.

[DNLM: 1. Quality of Health Care. 2. Choice Behavior. 3. Diabetes

Mellitus-therapy. 4. Patient Care. 5. Personal Autonomy. 6. Professional-

Patient Relations. W 84.1 M717L 2008a]

RA399.A1M6513 2008

$362.1-\mathrm{dc} 22$

2007047374

ISBN 0-203-92707-9 Master e-book ISBN

ISBN 10: 0-415-45342-9 (hbk)

ISBN 10: 0-415-45343-7 (pbk)

ISBN 10: 0-203-92707-9 (ebk)

ISBN 13: 978-0-415-45342-4 (hbk)

ISBN 13: 978-0-415-45343-1 (pbk)

ISBN 13: 978-0-203-92707-6 (ebk) 
For Elisabeth and Johannes 



\section{Contents}

Prologue ix

1 Two logics 1

Clichés of the West 2

Active patients 6

The method 8

The book 11

2 Customer or patient?

Product or process 16

Target group or team member 20

Dreams or support 23

Hoping for health or living with disease 26

Actors who let go 27

3 The citizen and the body

Control or attentiveness 31

Tame or nourish 34

Determined or alive 37

Who is in charge or what to do 40

4 Managing versus doctoring

Informative facts or target values 43

Means or modifiers 46

Calculating or attuning 50

Managing doctors or shared doctoring 54

5 Individual and collective

Pre-given individuals or careful individuation 59

Adding equals or crafting categories 62 


\section{viii Contents}

Healthy behaviour or helpful conditions 66

The hidden brave 70

6 The good in practice

Morality in action 74

Active patients 79

Improving health care 83

Translations 89

Acknowledgements 95

Notes 98

$\begin{array}{ll}\text { Literature } & 116\end{array}$

$\begin{array}{ll}\text { Index } & 126\end{array}$ 


\section{Prologue}

In this book I will contrast two ways of dealing with disease. One of these, the logic of care, is the central topic of this book, while the other, the logic of choice, forms its point of contrast. But let me begin by telling some stories. These could be presented either as personal experiences or as ethnographic observations, the difference is not really relevant. Together they index the events that led me to write this book, and they provide a first sense of the concerns that lie behind it.

Story one. It is the early 1980s. On Dutch television a discussion on in vitro fertilisation is about to be broadcast. As a young feminist scholar, studying biomedicine and its techniques, I sit down to watch how the promises and problems of IVF will be staged. No doubt there will be talk about much loved babies. But what about the impressive quantities of hormones that are injected into women in the course of this intervention? Will anyone mention the way that these women's lives are ordered around ovulation and egg-harvesting for months on end? Will the discussion dwell on the fact that parental hope for a child 'of their own' is being fuelled, even though in most cases it is never met? I realise that it is unlikely that any of the guests will contrast the emotional and financial investment made in any Western child with the fact that children in the rest of the world die in large numbers of hunger and infectious diseases. Nor will anyone ask why organising good daycare facilities seems so much less urgent than making babies. Yet I am curious.

After some preliminaries and explanations, the gynaecologist is asked to speak. However, he almost immediately shifts this task to 'the patient'. His patient. There she is: a woman who will appeal to many - she could be a professional herself, a feminist even, but also someone who gave up work once she got married. Presenting herself both as suffering and proud, she tells the audience that, yes, indeed, she has so far failed to get pregnant in the usual way. She wants a child very badly. Therefore, whatever the possible risks or drawbacks she is undergoing IVF. It is, she says, her own 
choice. At this point the camera shifts back to the gynaecologist. Who would be so paternalistic, he says, as to deny this woman her choice? End of discussion. As if it were a magic wand, the term 'choice' has ended the discussion. All the possible advantages and disadvantages of the treatment, all its goods and bads, have been turned into private concerns. They are not to be questioned. Interestingly, the gynaecologist's words come straight out of the abortion debate that had taken place in the Netherlands barely a decade earlier. There it is, the term 'paternalistic', which evokes male arrogance; 'her own' that makes the woman sound courageous; and finally there is 'choice', the very act that turns a person into a subject. What to say? The question of how to counter the magic of the term 'choice' has haunted me ever since.

Story two. Ten years on. I've kept on researching and writing. Now, as a supposedly neutral third party, I am invited to chair a discussion about choice and patient autonomy between ethicists and psychiatrists. One of the ethicists begins by presenting a case. Briefly: one morning a patient in an open ward of a psychiatric hospital does not want to get up. Question: are you going to allow him to stay in bed or not? (It is implied that 'you' are in the safe position of the psychiatrist, who may offer others the freedom to choose, or not. Somehow the 'you' of medical ethics is never a patient. But that is in parentheses.) Most of the ethicists in the meeting think the case is easy. A person who stays in bed does not harm anyone else. It is the pivotal liberal principle that people are allowed to make their own choices so long as they do not harm others. Let him be, this man, let him make his own choice. One ethicist sees a problem however. What if the person in question is incapable of functioning as a subject of choice, what if he - he's a patient after all - is insane? A discussion about madness ensues. Is a patient in a psychiatric hospital always 'mad' and incapable of making choices? Or is this only the case if he happens to be psychotic, acutely depressed or otherwise overwhelmed by disease? The question of autonomy gets linked up with that of psychiatric diagnosis. Thus the ethicists seem to silence themselves. For when it comes to diagnosis, the psychiatrists are the experts.

However, the psychiatrists present do not seem too worried about diagnosis. They have other concerns. One of them says that, since life in a hospital ward is communal, people have to adapt to shared rules. In a family, he says, you also have to join in for breakfast. Such routines make for a better daily life. Another psychiatrist stresses that people admitted to a psychiatric hospital often have to learn to make choices: this is a part of their treatment. So whether this particular patient is up to being confronted with the negative consequences of making a bad choice (no breakfast, no daytime activities) or should be encouraged to get up as a way of protecting him, depends on the stage of his treatment. Further responses go off in other directions. 
One of them is striking. The retired Professor of Psychotherapy says: it is all a question of money. He reproaches the ethicist who has presented the case for leaving out the institutional context. A dilemma like this, he says, only arises when there are not enough staff: 'On a ward with enough staff, I'd send a nurse to sit next to the patient's bed and ask why he does not want to get up. Maybe his wife is not coming for a visit that afternoon. Maybe he feels awful and fears he will never be released from hospital. Take time for him, let him talk.' Someone who does not want to get up, says the psychotherapist, needs care. Offering him the choice of staying in bed is as much a way of neglecting him as is forcing him to get up.

This is helpful. Yes, there is not only a contrast between 'choice' and 'no choice', but also between these two, united in a logic of choice, and an altogether different alternative, that of care, something that contrasts with neglect. Might it be possible, I wonder in the days, the years, that follow, to find ways of articulating a logic of care?

Story three. It is still the early 1990s. I am pregnant and 36. A national committee of experts in the Netherlands where I live has looked at the statistics and suggested that pregnant women over 35 should have an amniocentesis and thus the option of abortion should their foetus have Down's Syndrome. Given where I am (I have a healthy child and work that fascinates me and it is difficult enough as it is to juggle between them) I follow the advice. I take a day off and go to the hospital where I also happen to be doing the field work for the book that I am working on at the time. It is slightly strange to shift from the role of observer to that of patient. But I lie down on the examination table and feel the ultrasound probe moving over my belly. Still in my field-work habits, or just to break the silence, I say to the nurse who is preparing the long needle that will be inserted into my womb: 'I hope it all goes okay.' We both know that a small percentage of women have a spontaneous abortion as a result of the procedure. The nurse snaps back: 'Well, it is your own choice.'

Back home I dutifully sit down on the couch, legs up, to reduce the chance of the threatened spontaneous abortion. But I also start to make notes for what turns out to be field work after all, albeit for some future book. I wonder what the nurse might have said that would have fitted a logic of care. 'Let's indeed hope it goes well'; or 'Most of the time there's no problem'; or 'Are you worried about it?' She might have touched me in a kind way. And she might even have used the moment to encourage me to behave and say: 'You may want to have a quiet afternoon, then.' But instead she illustrates beautifully how mobilising the logic of choice can lead to poor care. It can shift the weight of everything that goes wrong onto the shoulders of the patient-chooser.

Over the last twenty years, 'choice' and more particularly 'patient 
choice' has attracted ever more public attention. Its public appeal has increased too. Over the same period I hit upon more and more reasons for doubting it. Thus, when early in the new century ZON/Mw, the Netherlands Organisation for Health Research and Development, offered grants for studies intended to 'increase the possibilities for patient choice', I wrote an application. It stated that, if it is compared with 'force', then 'choice' is more often than not a great good. But what about comparing it with 'care'? Is 'care' a soft form of 'force' or might something entirely different be going on? I got the grant which made it possible to investigate a specific set of care activities in more detail than provided in the examples above. I analysed them again and again and then gradually wrote this book. It argues that, indeed, in care practices something entirely different is going on. Care has a logic of its own. The logic of care. How to talk about it? 